UDC 338.45:620

\title{
ANALYSIS OF FINANCIAL AND ECONOMIC ACTIVITY OF STATE FOREST ENTERPRISES IN THE CONDITIONS OF ECONOMIC AND ECOLOGICAL CRISIS
}

Article info
Received
29.04 .2020
Accepted
24.06 .2020
Zhytomyr
National
Agroecological
University
7, Staryi Blvd,
Zhytomyr,
10008, Ukraine
E-mail:
marina_lis@
ukr.net

\author{
M. Shvets, F. Markov, A. Fitisov, P. Didenko
}

Shvets, M., Markov, F., Fitisov, A., Didenko, P. (2020). Analysis of financial and economic activity of state forest enterprises in the conditions of economic and ecological crisis. Scientific Horizons, 06 (91), 92-100. doi: 10.33249/2663-21442020-91-6-92-100.

The instability of environmental and economic situations requires forestry companies to be more thoroughly analytical in their management decisions. They also generate additional information needs for companies. The purpose of the paper was to analyze the financial and economic activity of forestry enterprises in the conditions of economic and environmental instability and to identify the main reasons for changes in forestry activity. Its implementation was ensured by economic, logical, statistical, etc. methods of research of financial and economic indicators of functioning of $P E$ "Emilchinskoe Forestry". The main tendencies of development of the forestry industry and their impact on the environment are highlighted. The dynamics of the main economic indicators of forestry activity on the example of PE "Emilchinskoe Forestry" for the period from 2017 to 2019 in the conditions of economic and environmental instability was analyzed. The obtained conclusions made it possible to predict the further development of financial and economic activity of the enterprise. The possibility of maintaining stability in particular regarding personnel policy in the conditions of economic instability was evaluated. There was a positive tendency towards an increase in average annual productivity per employee, which indicates the efficiency of the use of labor resources. At the same time, there is a negative tendency to outstrip the rate of growth of wages in comparison with the rate of growth of labor productivity, which contributes to the decrease in profitability of the enterprise. A negative trend is a decrease of the indicator of return on assets on 0.6 UAH. or $19.4 \%$. The situation is explained by the decrease in the total volume of production and sales of products. It was found that the volume of sold conversion products increased by $124.3 \%$. The results indicate a more efficient use of the merchantable volume, improvement of the assortment structure, as well as the creation of added value due to the volume of conversed wood. Overall, a negative tendency of decrease of solvency and liquidity level of the enterprise is revealed. The net profit of the forestry has more than doubled (by $56.2 \%$ ). The main factors that influenced this result are excessive taxes in the forestry industry, rising fees for forest resources, rising prices for basic materials and spare parts for production needs of the enterprise, instability of the national currency. All these factors were accompanied by a decrease in demand in the domestic market and, consequently, in prices for timber products. Further research requires the dissemination and access to statistical information and reports resulting from the activities of governmental research organizations and services.

Key words: economic analysis, forestry products, labor productivity, solvency, profitability. 


\title{
АНАЛІЗ ФІНАНСОВО-ГОСПОДАРСЬКОЇ ДІЯЛЬНОСТІ ЛІСОГОСПОДАРСЬКИХ ПІДПРИЕМСТВ В УМОВАХ ЕКОНОМІЧНОЇ ТА ЕКОЛОГІЧНОЇ НЕСТАБІЛЬНОСТІ
}

\author{
М. В. Швець, Ф. Ф. Марков, А. М. Фітісов, П. В. Діденко \\ Житомирський національний агроекологічний університет \\ бульвар Старий, 7, м. Житомир, 10008, Україна
}

Нестабільність екологічної та економічної ситуацій вимагають від підприємств лісової галузі більш ретельної аналітичної підготовки до прийняття управлінських рішень та формують додаткові потреби у інформачї. Метою роботи є проведення аналізу фінансово-господарської діяльності лісогосподарських підприємств в умовах економічної та екологічної нестабільності $і$ виявлення основних причин зміни показників лісогосподарської діяльності. Ї̈ реалізацію забезпечило проведене за допомогою економіко-логічних, статистичних та інших методів дослідження фінансовогосподарських показників функиіонування ДП «Ємільчинське лісове господарство». Виокремлено основні тенденції розвитку галузі лісового господарства та їх вплив на навколишнє середовище. Проаналізовано динаміку основних економічних показників лісогосподарської діяльності на прикладі ДП «Смільчинське ЛГ» за період з 2017 по 2019 рр. в умовах економічної та екологічної нестабільності, що дало змогу оцінити його фінансовий стан $i$, на основі отриманих висновків, спрогнозувати подальший розвиток фінансово-господарської діяльності. Оиінено можливість підтримання стабільності зокрема щодо кадрової політики в умовах економічної нестабільності. Відмічено позитивну тенденщію відносно збільшення середньорічної продуктивності праці на 1 прачівника, щзо свідчить про ефективність використання трудових ресурсів. У той же час, спостерігається негативна тенденція щуодо випередження темпів росту заробітної плати порівняно із темпами росту продуктивності праиі, щзо виливає на зменшення прибутковості підприємства. Негативною тенденцією є зниження показника фондовіддачі на 0,6 грн, або 19,4 \%, щзо пояснюється зменшенням загальних обсягів виробництва, а відповідно і реалізаџї продукиії. Встановлено, що обсяг реалізованої продукиії переробки зріс на 124,3\%, а питома вага у 2019 р. досягла значення 53,4 \% у загальній структурі реалізачії, щзо на $9 \%$ більще, ніж було у 2017 р. Даний аналіз свідчить про ефективніше використання лісосічного фонду лісгоспу, покращення сортиментної структури, а також створення доданої вартості за рахунок обсягів переробленої деревини. Загалом виявлена негативна тенденція з роками щзодо рівня платоспроможності та ліквідності підприємства. Чистий прибуток лісгоспу знизився більше, ніж у два рази (на 56,2%). Основними чинниками, які вплинули на даний результат, є надмірні податки в лісовій галузі, зростання плати за використання лісових ресурсів, зростання иін на основні матеріали та запасні частини для виробничих потреб підприємства, нестабільність національної валюти за умови, щзо лісгосп експортує $55 \%$ усієі продукції. Всі иі перелічені чинники супроводжувалися зниженням попиту на внутрімньому ринку, а відповідно і иін на лісопродукцію, що визначило діяльність підприємства. Подальших досліджень потребують питання поширення та відкриття доступу до статистичної інформачї̈ та звітів, щњо $\epsilon$ результатами діяльності державних науково-дослідних організачій та служб.

Ключові слова: економічний аналіз, лісогосподарська продукція, продуктивність прачі, платоспроможність.

\section{Вступ}

Фінансово-економічний аналіз відіграє важливу роль в оцінюванні господарської діяльності будь-якого підприємства (Chumachenko, 2001; Kostenko et al., 2005). Аналіз показників традиційно базується на даних, що забезпечує існуюча система бухгалтерського обліку та звітності. Основними завданнями фінансово-економічного аналізу $\epsilon$ прийняття оптимальних управлінських рішень, які можуть забезпечити мінімізацію витрат при максимально можливих результатах за наявних ресурсів, 3 урахуванням сталого збалансованого природокористування (Banasko, 2009; Shershun, 2012; Vasiltsev et al., 2012).

Оцінити формування доходів і витрат лісогосподарських підприємств, стану їх господарських засобів, рентабельність тощо можливо, використовуючи дані, що знаходяться у відкритому доступі. Така доступність даних 
M. Shvets, F. Markov, A. Fitisov, P. Didenko

забезпечує науковців, аналітиків та управлінський персонал можливістю здійснювати оцінку господарської діяльності підприємств галузі, порівнювати результати їх діяльності та робити припущення щодо майбутніх тенденцій їх розвитку. Однак, наявні дані мають певні обмеження щодо їх застосування та не здатні забезпечити підгрунтя для повної оцінки ситуації у галузі, особливо в умовах економічної та екологічної нестабільності.

Процес вивчення проблеми повноти даних щодо діяльності підприємств лісогосподарської галузі базувався на прикладі ДП «Смільчинське лісове господарство». Дане підприємство є одним iз найбільш економічно стабільних у галузі впродовж багатьох років. Лісистість адміністративних районів (Смільчинський та НовоградВолинський), на території яких розташоване ДП «Смільчинське лісове господарство», складає $36,4 \%$. На території району ліси розташовані нерівномірно, значно більше їх у північнозахідній частині. Загальна площа ДП «Емільчинське ЛГ» становить 51,1 тис. га. Господарська діяльність підприємства спрямована на підвищення продуктивності лісів, забезпечення їхньої охорони та відтворення, підвищення корисних властивостей (Torosov et al., 2012; Krivka \& Stonkute, 2015; Chik, 2017). Показники використання лісосічного фонду, обсяги лісовідновних робіт, середні таксаційні показники та інші дані вказують на досить високу інтенсивність ведення лісового господарства. Ступінь забезпечення транспортними засобами, виробничими фондами, трудовими ресурсами становить $100 \%$. Нестача в окремі періоди поповнюється за рахунок сезонних і тимчасових робітників (Klimovych \& Tatiievska, 2018; Lysychko, 2018; Tkachiv \& Nykytjuk, 2017). Основні сортименти, які заготовлюються в лісгоспі: лісоматеріали круглі, дров'яна деревина промислового використання, дров'яна деревина непромислового використання. Найбільшими споживачами деревини є внутрішній ринок. На власні потреби, включаючи і потреби цехів переробки деревини, використовується близько 45 тис. $\mathrm{m}^{3}$ лісопродукції. Нами проаналізовано динаміку основних економічних показників діяльності лісгоспу за період економічної кризи (2017-2019 рр.), що дало змогу оцінити його фінансовий стан і, на основі отриманих висновків, спрогнозувати подальший розвиток фінансовогосподарської діяльності підприємства.
Метою роботи є проведення аналізу фінансово-господарської діяльності лісогосподарських підприємств в умовах економічної та екологічної нестабільності і виявлення основних причин зміни показників лісогосподарської діяльності.

Об'єкт дослідження - результати фінансовогосподарської діяльності лісогосподарських підприємств в умовах економічної та екологічної нестабільності.

\section{Матеріали та методи}

У роботі застосовано монографічний, економіко-логічні, статистичні, табличний, графічний методи дослідження i метод порівняння. Для аналізу основних економічних показників підприємства була використана фінансова звітність лісгоспу за 2017-2019 рр. (баланс, звіт про фінансові результати, звіт про використання фінансового плану), статистична звітність (форма 1-ПВ, форма 3-ЛГ), форма 10-ЛГ, звіт про випуск товарної продукції.

\section{Результати дослідження та обговорення}

Нестабільність екологічної та економічної ситуацій вимагають від підприємств лісової галузі більш ретельної аналітичної підготовки до прийняття управлінських рішень та формують додаткові потреби у інформації. 3 метою виявлення даних, що наразі не мають повного відображення у відкритих джерелах, однак є необхідними для повноцінного аналізу діяльності лісогосподарських підприємств, було проведено оцінку окремих фінансово-господарських показників функціонування ДП «Ємільчинське лісове господарство». Оцінка дозволила встановити факт, що у вільному доступі знаходиться не вся необхідна інформація. Виокремлено складові (закриті звіти), що здатні доповнити наявні набори показників та сформувати 3 них повноцінну систему даних. Така система могла б бути базою розрахунків аналітичних звітів та прогнозів (рис. 1).

Одним із основних завдань підприємства $\epsilon$ забезпечення його трудовими ресурсами. Нами простежена динаміка середньооблікової чисельності працівників та ефективності використання промислово-виробничого персоналу в господарстві (табл. 1). 
M. Shvets, F. Markov, A. Fitisov, P. Didenko

\begin{tabular}{|c|c|}
\hline $\begin{array}{c}\text { Аналіз внутрішніх умов } \\
\text { функціонування підприємства }\end{array}$ & $\begin{array}{c}\text { Аналіз зовнішніх умов } \\
\text { функціонування підприємства }\end{array}$ \\
\hline $1 L$ & $1 L$ \\
\hline $\begin{array}{c}\text { Показники фінансово- } \\
\text { господарської діяльності підприємства }\end{array}$ & $\begin{array}{lcc}\text { Показники } & \text { стану та } & \text { прогноз } \\
\text { зовнішнього } & \text { середовища } & \text { функціо- } \\
\text { нування підприємства } & \end{array}$ \\
\hline \begin{tabular}{ll}
\multicolumn{1}{c}{} \\
• & природні умови \\
• & виробничі показники \\
• & організаційні умови \\
• & збутові показники \\
• & кадри та показники їх
\end{tabular} & $\rightarrow \mid \begin{array}{l}\text { Зовнішні економічні показники та } \\
\text { прогноз іх змін (ринки капіталу, } \\
\text { соціальна та податкова політика, } \\
\text { наявність торговельних та інших } \\
\text { обмежень тощо) }\end{array}$ \\
\hline $\begin{array}{ll} & \text { використання } \\
\text { • } & \text { маркетингові показники } \\
\text { • } & \text { фінансові показники }\end{array}$ & $\rightarrow \begin{array}{l}\text { Зовнішні екологічні i природно- } \\
\begin{array}{l}\text { кліматичні показники та прогноз їх } \\
\text { змін }\end{array}\end{array}$ \\
\hline $1 L$ & 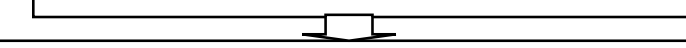 \\
\hline
\end{tabular}

Рис. 1. Система показників для розрахунку аналітичних звітів та прогнозів

Таблиия 1. Динаміка середньооблікової чисельності працівників та ефективності використання персоналу у ДП «Ємільчинське ЛГ»

\begin{tabular}{|l|c|c|c|c|c|}
\hline \multicolumn{2}{|c|}{ Показники } & \multicolumn{3}{c|}{ Рік } & \multicolumn{2}{c|}{ Відхилення } \\
\cline { 2 - 7 } & $\mathbf{2 0 1 7}$ & $\mathbf{2 0 1 8}$ & $\mathbf{2 0 1 9}$ & \% & \% \\
\hline $\begin{array}{l}\text { Середньооблікова чисельність працівників, } \\
\text { осіб }\end{array}$ & 499 & 523 & 507 & 8 & 101,6 \\
\hline $\begin{array}{l}\text { Середньорічна продуктивність праці на } \\
\text { працівника, тис. грн }\end{array}$ & 324,3 & 363,3 & 330,3 & 6,0 & 101,9 \\
\hline Загальний фонд оплати праці, тис. грн & 45677,0 & 61895,0 & 58874,0 & 13197,0 & 128,9 \\
\hline $\begin{array}{l}\text { Середньомісячна заробітна плата на } \\
\text { працівника, грн }\end{array}$ & 7628 & 9862 & 9677 & 2049 & 126,9 \\
\hline
\end{tabular}

У сучасних умовах економічної кризи ДП «Ємільчинське ЛГ» вдалося зберегти стабільну ситуацію щодо кадрової політики. Спостерігається позитивна тенденція відносно збільшення середньорічної продуктивності праці на 1 працівника, що свідчить про ефективність використання трудових ресурсів. Так, рівень продуктивності праці зріс на 6 тис. грн, що становить $101,9 \%$. Також вдалось досягти збільшення середньомісячної заробітної плати, яка зросла на 2049 грн або 126,9\%. Середньомісячна заробітна плата у розмірі 9677 грн є вищою, ніж у середньому по Україні. У той же час, спостерігається негативна тенденція щодо випереджання темпів росту заробітної плати порівняно із темпами росту продуктивності праці, що впливає на зменшення прибутковості підприємства (Ostapiuk, 2011). Тому у найближчий період одним із основних завдань лісгоспу $\epsilon$ збалансування темпів росту продуктивності праці $\mathrm{i}$ заробітної плати для покращення його фінансових результатів.

Показники використання підприємством трудових ресурсів є одними 3 ключових. Адже вони, 3 одного боку, забезпечують функціонування підприємства, а 3 іншого формують одні з головних джерел його витрат. До того ж, проблема міграції працездатного населення $є$ однією з найскладніших економічних та соціальних викликів для країни. В таких умовах важливими є здатність вчасно реагувати на зміни соціальних стандартів, галузевих вимог, 
а також можливість гнучкої маніпуляції інструментами, що забезпечують ефективність використання персоналу. Це вимагає наявності чіткої загальнодержавної та галузевої політики у цій сфері та доступність таких даних для усіх зацікавлених сторін.

Одним із факторів розвитку підприємства та досягнення поставлених цілей $\epsilon$ забезпечення його основними фондами (табл. 2).

Таблиия 2. Забезпечення ДП «Емільчинське ЛГ» основними фондами

\begin{tabular}{|l|l|l|l|l|l|}
\hline \multicolumn{2}{|c|}{ Показники } & \multicolumn{3}{c|}{ Рік } & \multicolumn{2}{c|}{ Відхилення } \\
\cline { 2 - 6 } & \multicolumn{1}{|c|}{$\mathbf{2 0 1 7}$} & $\mathbf{2 0 1 8}$ & $\mathbf{2 0 1 9}$ & \multicolumn{1}{c|}{+} & \% \\
\hline $\begin{array}{l}\text { Середньорічна вартість основних фондів, } \\
\text { тис. грн }\end{array}$ & 51393,5 & 59947,0 & 66054,5 & 14661,0 & 128,5 \\
\hline Фондоозброєність праці, тис. грн & 103,0 & 114,6 & 130,3 & 27,3 & 126,5 \\
\hline Фондовіддача, грн & 3,1 & 3,2 & 2,5 & $-0,6$ & 80,6 \\
\hline Фондомісткість, грн & 0,32 & 0,31 & 0,40 & 0,08 & 125,0 \\
\hline
\end{tabular}

Як бачимо 3 вищенаведеної таблиці, підприємству вдалося наростити вартість основних фондів на 128,5\%, що свідчить про достатньо високий виробничий потенціал лісгоспу. Зафіксовано зростання показника фондоозброєності праці на $126,5 \%$. Негативною тенденцією $є$ зниження показника фондовіддачі на 0,6 грн, або 19,4\%. Це можна пояснити зменшенням загальних обсягів виробництва, а відповідно і реалізації продукції, що буде проаналізовано нижче (табл. 3).

\section{Таблиия 3. Структура реалізації продукції за період 2017-2019 pp.} у ДП «Емільчинське ЛГ»

\begin{tabular}{|c|c|c|c|c|c|c|c|c|c|}
\hline \multirow{2}{*}{ Найменування } & \multicolumn{2}{|c|}{2017 p. } & \multicolumn{2}{|c|}{2018 p. } & \multicolumn{2}{|c|}{2019 p. } & \multicolumn{3}{|c|}{ Відхилення } \\
\hline & тис. грн & $\%$ & тис. грн & $\%$ & тис. грн & $\%$ & $+\%$ & $\%$ & II. c. \\
\hline Лісоматеріали круглі & 42875 & 26,5 & 52574 & 27,7 & 46682 & 27,9 & 3807 & 108,9 & 1,4 \\
\hline \begin{tabular}{|l|} 
Дров'яна деревина \\
промислового \\
використання
\end{tabular} & 20453 & 12,6 & 33896 & 17,8 & 16645 & 9,9 & -3808 & 81,4 & $-2,7$ \\
\hline $\begin{array}{l}\text { Дров'яна деревина } \\
\text { непромислового } \\
\text { використання }\end{array}$ & 22743 & 14,1 & 11813 & 6,2 & 6455 & 3,9 & -16288 & 28,4 & $-10,2$ \\
\hline $\begin{array}{l}\text { Перероблена } \\
\text { деревина }\end{array}$ & 71900 & 44,4 & 83140 & 43,8 & 89399 & 53,4 & 17499 & 124,3 & 9 \\
\hline $\begin{array}{l}\text { Послуги у лісовому } \\
\text { господарстві }\end{array}$ & 3832 & 2,4 & 8603 & 4,5 & 8295 & 4,9 & 4463 & 216,5 & 2,5 \\
\hline Всього & 161803 & 100,0 & 190026 & 100,0 & 167476 & 100,0 & 5673 & 103,5 & - \\
\hline
\end{tabular}

Наведені у табл. 3 дані свідчать про зміну структури реалізованої продукції. Так, обсяг реалізованої продукції переробки зріс на $124,3 \%$, а питома вага у 2019 р. досягла значення $53,4 \%$ у загальній структурі реалізації, що на $9 \%$ більше, ніж було у 2017 р. (рис. 2). Впровадження мораторію на заборону реалізації круглих лісоматеріалів на експорт стало ключовим чинником збільшення продукції переробки. У цілях лісгоспу - досягти значення реалізації переробки до $60 \%$ від загальної реалізації у найближчий рік.
Також необхідно звернути увагу на значне скорочення питомої ваги дров'яної деревини непромислового та промислового використання, відповідно, на $10,2 \%$ та $2,7 \%$. У свою чергу, питома вага круглих лісоматеріалів у структурі реалізації становить $27,9 \%$, що більше у порівнянні з 2017 р. на 1,4 \% (рис. 3). Даний аналіз свідчить про ефективніше використання лісосічного фонду лісгоспу, покращення сортиментної структури, а також створення доданої вартості за рахунок обсягів переробленої деревини. 
M. Shvets, F. Markov, A. Fitisov, P. Didenko

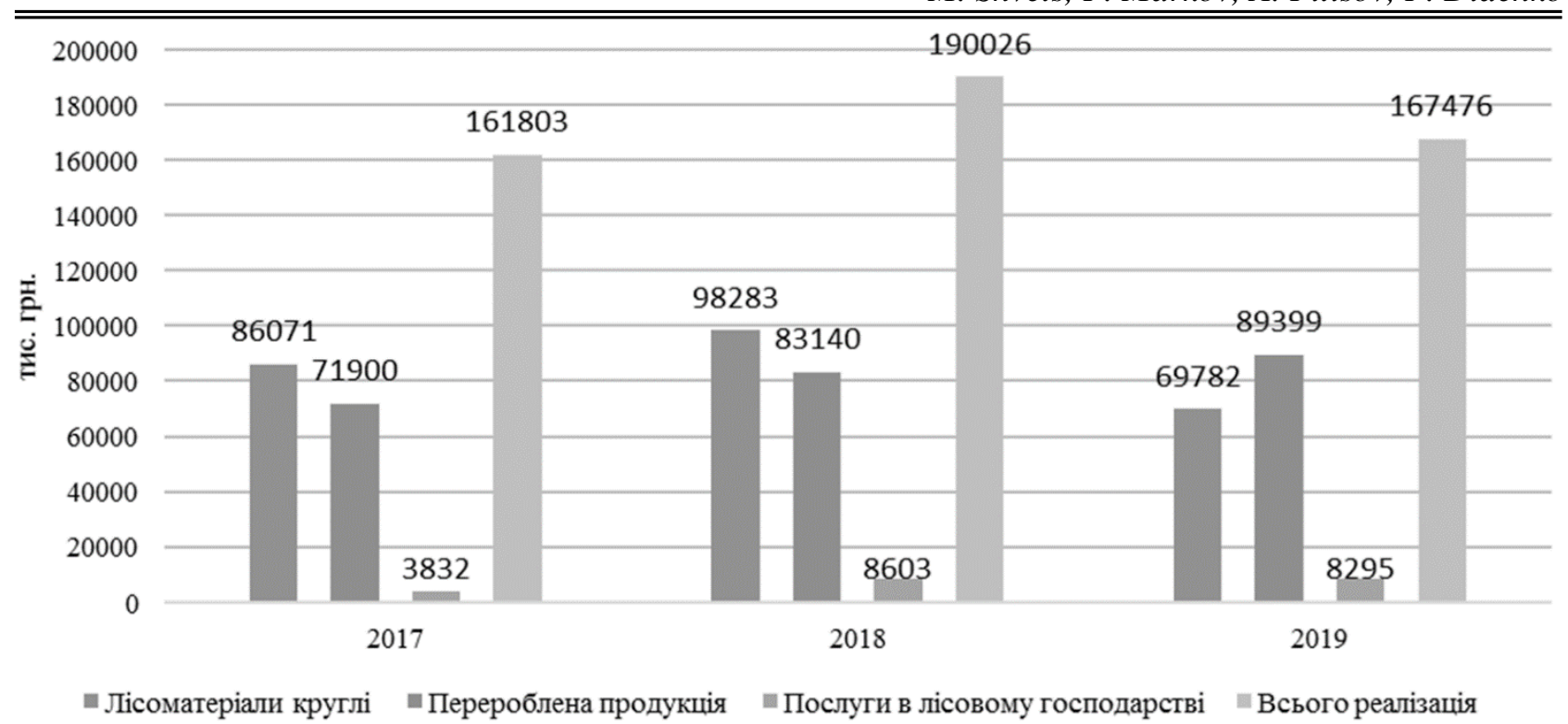

Рис. 2. Динаміка обсягів реалізації продукції у ДП «Ємільчинське ЛГ»

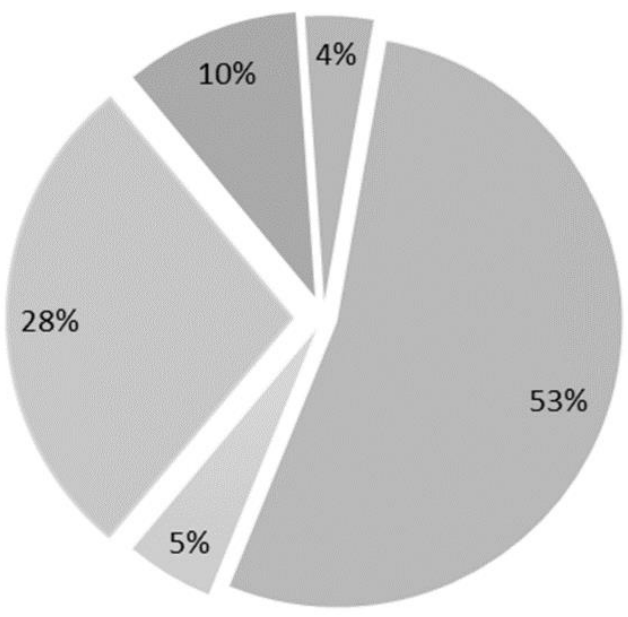

\# Лісоматеріали круглі

- Дров'яна деревина

промислового використання

- Дров'яна деревина

непромислового

використання

- Перероблена деревина

Послуги у лісовому

господарстві

Рис. 3. Структура реалізації продукції на підприємстві у 2019 р.

Показники виробництва та реалізації продукції $\epsilon$ основними індикаторами стану самого підприємства, а також впливу на нього чинників внутрішнього та зовнішнього середовища існування. Окремо слід зупинитися на тому, що ведення лісогосподарської діяльності підприємств визначають природно-кліматичні та екологічні фактори. I саме доступ до інформації, що забезпечувала б обгрунтовані прогнози зміни названих чинників, здатні вплинути на управлінські рішення та стратегічні плани підприємств.

Аналіз фінансового стану $є$ важливим елементом аудиту, складовою частиною загального економічного аналізу діяльності підприємства. Основною метою такого аналізу є надання інформації користувачам про прибутковість, платоспроможність, ділову активність і фінансову стійкість господарства (табл. 4).

Аналіз даних таблиці свідчить, що у 2019 р., порівняно з 2017 р., чистий дохід зріс на 103,5 \%. Основною причиною є збільшення питомої ваги продукції переробки у загальній реалізації. Виробнича собівартість також зросла на 116,6 \%, що пояснюється, в першу чергу, підвищенням цін на паливно-мастильні матеріали, а також ростом фонду оплати праці виробничого персоналу. Валовий прибуток зменшився на $30,9 \%$ за рахунок зростання виробничої собівартості порівняно з чистим доходом. 
M. Shvets, F. Markov, A. Fitisov, P. Didenko

Таблиия 4. Аналіз фінансових результатів ДП «Смільчинське ЛГ», тис. грн

\begin{tabular}{|l|c|c|c|c|c|}
\hline \multicolumn{2}{|c|}{ Показники } & \multicolumn{3}{c|}{ Рік } & \multicolumn{2}{c|}{ Відхилення } \\
\cline { 2 - 6 } & $\mathbf{2 0 1 7}$ & $\mathbf{2 0 1 8}$ & $\mathbf{2 0 1 9}$ & \%. & \% \\
\hline $\begin{array}{l}\text { Чистий дохід від реалізації продукції та } \\
\text { наданих послуг }\end{array}$ & 161803,0 & 190026,0 & 167476,0 & 5673,0 & 103,5 \\
\hline $\begin{array}{l}\text { Виробнича собівартість } \\
\text { продукції }\end{array}$ & 117222,0 & 148646,0 & 136683,0 & 19461,0 & 116,6 \\
\hline Валовий прибуток & 44581,0 & 41380,0 & 30793,0 & $-13788,0$ & 69,1 \\
\hline Інші операційні доходи & 1967,0 & 3504,0 & 621,0 & $-1346,0$ & 31,6 \\
\hline Адміністративні витрати & 6409,0 & 6992,0 & 6190,0 & $-219,0$ & 96,6 \\
\hline Витрати на збут & 31273,0 & 29551,0 & 19849,0 & $-11424,0$ & 63,5 \\
\hline Інші операційні витрати & 4066,0 & 6496,0 & 3313,0 & $-753,0$ & 81,5 \\
\hline Прибуток від операційної діяльності & 4800,0 & 1845,0 & 2062,0 & $-2738,0$ & 43,0 \\
\hline Прибуток до оподаткування & 4957,0 & 2005,9 & 2205,0 & $-2752,0$ & 44,5 \\
\hline Чистий прибуток & 3973,0 & 1625,0 & 1742,0 & -2231 & 43,8 \\
\hline
\end{tabular}

Суму адміністративних витрат вдалося скоротити на 219 тис. грн, що становить 3,4\%. Такої економії вдалося досягти за рахунок витрат на утримання апарату управління, в першу чергу, заробітної плати адміністративного персоналу, оскільки такі затрати в загальній структурі загальногосподарських витрат становлять більше
$70 \%$. Збутові витрати знизились на $36,5 \%$, що більше ніж 11 млн грн у рік. Таке значне падіння витрат обумовлюється відмовою підприємства транспортувати продукцію залізницею, на користь власного великогабаритного автотранспорту (рис. 4).

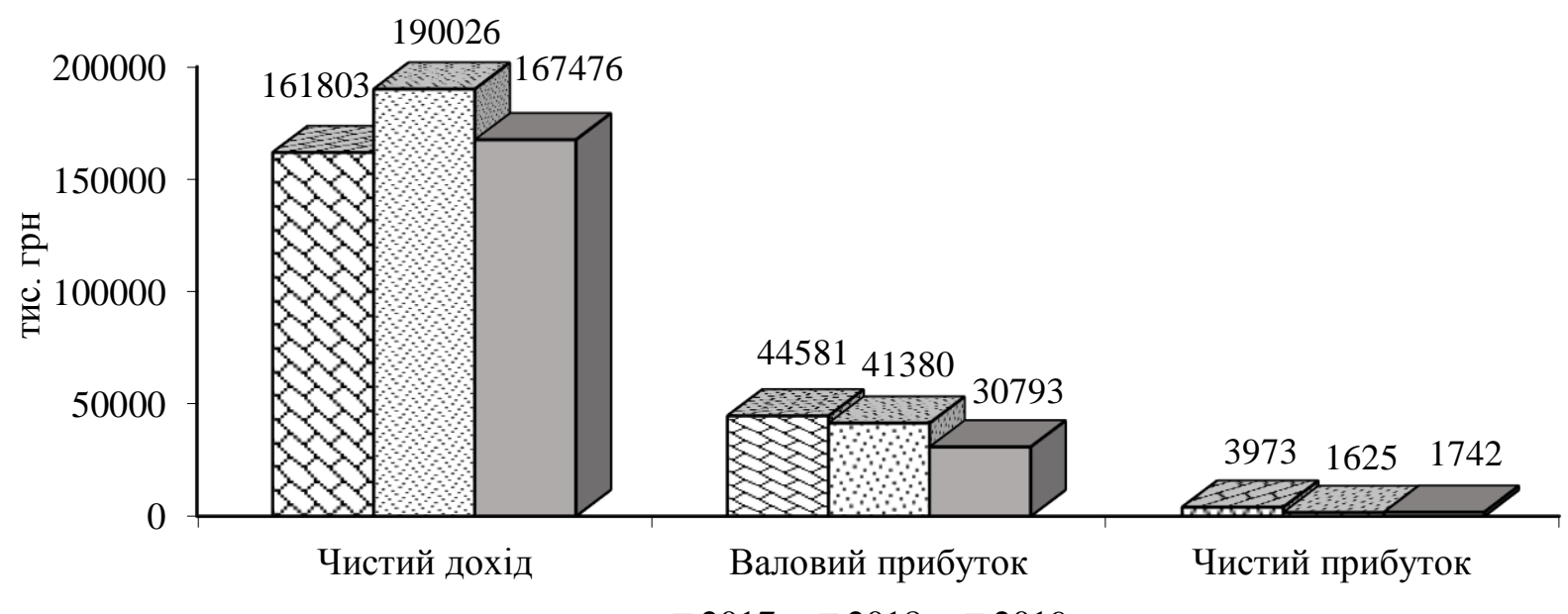

๑2017 ■2018 2019

Рис. 4. Динаміка основних показників діяльності ДП «Смільчинське ЛГ», 2017-2019 рр.

Одним 3 найважливіших показників ефективності діяльності підприємства $є$ розмір чистого прибутку. На досліджуваному підприємстві показник впав більше, ніж у два рази (на $56,2 \%)$. Ліквідність характеризує здатність підприємства реалізовувати свої активи, якими воно володіє, для погашення поточних зобов'язань 3 урахуванням термінів, а також свідчить про платоспроможність господарства (табл. 5).

Коефіцієнт абсолютної ліквідності зменшився на 0,18 за рахунок скорочення коштів лісгоспу на банківських рахунках на кінець 2019 р. Щодо коефіцієнта швидкої ліквідності спостерігаємо позитивну тенденцію iз збільшенням даного показника на 0,03 пункти. 
M. Shvets, F. Markov, A. Fitisov, P. Didenko

Таблиия 5. Аналіз динаміки показників ліквідності ДП «Емільчинське ЛГ» за 2017-2019 рр.

\begin{tabular}{|c|c|c|c|c|}
\hline \multirow{2}{*}{ Показники } & \multicolumn{3}{|c|}{ Рік } & \multirow{2}{*}{ Відхилення, + . } \\
\cline { 2 - 3 } & $\mathbf{2 0 1 7}$ & $\mathbf{2 0 1 8}$ & $\mathbf{2 0 1 9}$ & $-0,18$ \\
\hline Коефіціснт абсолютної ліквідності & 0,20 & 0,30 & 0,02 & 0,03 \\
\hline Коефіцієнт швидкої ліквідності & 0,55 & 0,63 & 0,58 & $-0,41$ \\
\hline Коефіцієнт покриття & 1,44 & 1,49 & 1,03 & \\
\hline
\end{tabular}

Причиною зростання $є$ збільшення виробничих запасів на складах підприємства. Коефіцієнт загальної ліквідності (покриття) знизився на 0,41 пункти. Основними чинниками $є$ накопичення поточних зобов'язань за рахунок заборгованості щодо виплат заробітної плати і розрахунків 3 контрагентами за постачання паливномастильних матеріалів та запасних частин. Загалом виявлена негативна тенденція 3 роками щодо рівня платоспроможності та ліквідності підприємства.

Основним показником, який характеризує ефективність фінансово-господарської діяльності підприємства є рентабельність (Derzhavne ..., 2013). Нами здійснено аналіз рентабельності ДП «Смільчинське ЛГ» i наведено результати розрахунків за 2017-2019 рр. (табл. 6).

Таблиця 6. Аналіз рентабельності господарської діяльності ДП «Смільчинське ЛГ» 3а 2017-2019 рр., \%

\begin{tabular}{|l|c|c|c|c|}
\hline \multirow{2}{*}{\multicolumn{1}{|c|}{ Показники }} & \multicolumn{3}{|c|}{ Рік } & \multirow{2}{*}{ Відхилення, + . } \\
\cline { 2 - 4 } & $\mathbf{2 0 1 7}$ & $\mathbf{2 0 1 8}$ & $\mathbf{2 0 1 9}$ & $-1,5$ \\
\hline Рентабельність діяльності & 2,5 & 0,9 & 1,0 & $-5,8$ \\
\hline Рентабельність активів & 9,4 & 3,5 & 3,6 & $-7,6$ \\
\hline Рентабельність власного капіталу & 12,8 & 4,8 & 5,2 & $-19,6$ \\
\hline Рентабельність продукції & 38,0 & 21,8 & 18,4 & \\
\hline
\end{tabular}

Рентабельність діяльності підприємства у 2019 р. становила 1,0\%, що на 1,5\% менше, ніж у 2017 р. Причиною зменшення даного показника є зниження чистого прибутку на суму 2231,0 тис. грн. Рівень рентабельності активів знизився на 5,8 \% за рахунок менш ефективного використання оборотних і необоротних активів підприємства. Відбулося зменшення показника рентабельності продукції на 19,6 \%, у зв’язку зі збільшенням собівартості продукції на суму 19461,0 тис. грн. Отже, даний аналіз свідчить про зниження ефективності виробництва та загалом господарської діяльності підприємства. Основними чинниками, які вплинули на даний результат, є надмірні податки в лісовій галузі, зростання плати за використання лісових ресурсів, зростання цін на основні матеріали та запасні частини для виробничих потреб підприємства, нестабільність національної валюти за умови, що лісгосп експортує 55 \% усієї продукції. Всі ці перелічені чинники супроводжувалися зниженням попиту на внутрішньому ринку, а відповідно і цін на лісопродукцію (Bublyk et al., 2019; Kuprina et al., 2019). А відтак, те, що підприємства галузі змушені працювати в умовах невизначеності та постійного браку відповідної інформації ускладнюють і так достатньо ризикову (з огляду на вплив природних чинників) діяльність.

\section{Висновки}

Встановлено, що проведений на прикладі ДП «Смільчинське ЛГ» аналіз показників фінансовогосподарської діяльності дозволив виокремити основні тенденції впливу зазначених чинників на стан та розвиток підприємства. Досліджуване підприємство опинилося в умовах скороченого попиту на лісопродукцію, крім того, запровадження мораторію на експорт лісоматеріалів у круглому вигляді призвело до перевищення пропозиції лісопродукції на внутрішньому ринку та, відповідно, зниження цін. Визначено, що зазначені економічні тенденції призвели у досліджуваному випадку до зниження показників фінансових результатів підприємства, ефективності та рентабельності його діяльності. Таке погіршення фінансових результатів $\epsilon$ наслідком не тільки ситуації на ринку лісоматеріалів, а також збільшення виробничих витрат підприємства (за рахунок підвищення плати за використання лісових ресурсів, зростанням цін за запасні частини, паливномастильні матеріали, зростання витрат на оплату праці). Спад фінансових результатів пов'язаний також iз більш швидкими темпами росту заробітної плати в порівнянні із ростом продуктивності праці. 
M. Shvets, F. Markov, A. Fitisov, P. Didenko

Доведено, що для стабілізації фінансовоекономічних показників, а в подальшому їхнього росту, підприємствам лісової галузі доцільно збільшити обсяги переробки деревини в поєднанні з оптимізацією виробничо-промислового персоналу, покращити відбір цінних сортиментів, що якісно змінить структуру заготівлі та реалізації лісопродукції. Перелічені заходи дадуть можливість підвищити рівень цін, знизити собівартість одиниці продукції, що позитивно вплине на величину чистого прибутку та рентабельності підприємства.

\section{References}

Banasko, T. M. (2009). Ekonomichnyi analiz vykorystannia nematerialnykh aktyviv: znachennia ta metodyka zdiisnennia [Economic analysis of the use of intangible assets: value and method of implementation]. Visnyk ZhDTU, 4, 6-11. doi: http://dx.doi.org/10.26642/jen-2009-4(50)-6-11 [in Ukrainian].

Bublyk, M., Petryshyn, N. \& Medvid, R. (2019). Analysis of export policy of timber trade in the conditions of international economic activity. Economic Analysis, 29 (3), 5-11. doi: http://dx.doi.org/10.35774/econa2019.03.005.

Chik, M. Yu. (2017). Aspekty ekonomichnoho analizu na pidpryiemstvakh lisovoho hospodarstva [Aspects of economic analysis in forestry enterprises]. Visnyk ZhDTU, 4, 60-64. doi: https://doi.org/10.26642/jen-2017-4(82)-60-64 [in Ukrainian].

Chumachenko, M. H. (2001). Economic analysis. Study guide. Kyiv: KNEU.

Derzhavne ahentstvo lisovykh resursiv Ukrainy (2013). Metodychni rekomendatsii z formuvannia sobivartosti produktsii (robit, posluh) na pidpryiemstvakh, shcho nalezhat do sfery upravlinnia Derzhavnoho ahentstva lisovykh resursiv Ukrainy [Methodical recommendations for formation of cost of production (works, services) at the enterprises belonging to the sphere of management of the State Agency of Forest Resources of Ukraine]. Retrieved from http://search.ligazakon.ua/1_doc2.nsf/link1/ FN011487.html [in Ukrainian].

Klimovych, I. M. \& Tatiievska, K. A. (2018). Deiaki pytannia sutnosti ta otsinky finansovoho stanu pidpryiemstva [Some questions about the nature and assessment of the financial condition of the enterprise]. Efektyvna ekonomika, 10 . doi: 10.32702/2307-2105-2018.10.62 [in Ukrainian].

Kostenko, T. D., Pidhora, Ye. O., Ryzhykov, V. S., Pankov, V. A., Herasymov, A. A. \& Rovenska, V. V.
(2005). Ekonomichnyi analiz i diahnostyka stanu suchasnoho pidpryiemstva [Economic analysis and diagnostics of modern enterprise]. Kyiv: Tsentr navchalnoi literatury [in Ukrainian].

Krivka, A. \& Stonkute, E. (2015). Complex analysis of financial state and performance of construction enterprises. Business, Management and Education, 13, 220-233. doi: https://doi.org/10.3846/bme.2015.300.

Kuprina, N., Volodina, O. \& Zavatska, Yu. (2019). Features of the analysis of financial results of the enterprise activities in modern conditions. Food Industry Economics, 11 (3), 40-49. doi : https://doi.org/10.15673/fie.v11i3.1460.

Lysychko, A. M. (2018). Ekonomichnyi analiz biznes-protsesiv lisohospodarskykh pidpryiemstv [Economic analysis of business processes of forestry enterprises]. Problemy teorii ta metodolohii bukhhalterskoho obliku, kontroliu i analizu, 1, 74-82. doi: http://dx.doi.org/10.26642/pbo-2018-1(39)-7482 [in Ukrainian].

Mnykh, E. (2003). Economic analysis: Reference book. Kyiv: Centre of educationalmaterial.

Ostapiuk, N. A. (2011). Metodyka otsinky finansovoho stanu pipdryiemstva $\mathrm{v}$ umovakh infliatsii [Methods of estimating the financial status of piped enterprise under inflation]. Visnyk ZhDTU, 1, 127-129 doi: https://doi.org/10.26642/jen-20111(55)-127-129 [in Ukrainian].

Shershun, M. (2012). Analiz finansovohospodarskoi diialnosti pidpryiemstv lisovoho hospodarstva Ukrainy [Analysis of financial and economic activity of Ukrainian forestry enterprises.]. Ekonomichnyi analiz, 10, 141-144 [in Ukrainian].

Tkachiv, S. M. \& Nykytiuk, P. A. (2017). Analiz finansovo-hospodarskykh pokaznykiv lisovoho hospodarstva rehionu [Analysis of financial and economic indicators of forestry in the region]. Ekonomika i suspilstvo, 9, 864-868 [in Ukrainian].

Torosov, A. S., Zhezhkun, I. M. \& Zujev, Je. S. (2012). Diahnostyka finansovoho stanu lisohospodarskoho pidpryiemstva $\mathrm{v}$ systemi antykryzovoho upravlinnia [Diagnosis of the financial condition of the forestry enterprise in the crisis management system]. Lisovyi zhurnal, 1, 48-53 [in Ukrainian].

Vasyltsiv, T. H., Voloshyn, V. I., Boikevych, O. R. \& Karkavchuk, V. V. (2012). Finansovo-ekonomichna bezpeka pidpryiemstv Ukrainy: stratehiia ta mekhanizmy zabezpechennia [Financial and economic security of Ukrainian enterprises: strategy and support mechanisms]. Lviv : Liha-Pres [in Ukrainian]. 